\title{
Military intervention in Syria: The American, British and French alternatives and the Russian option
}

Johan $\mathrm{D}$ van der Vyver

BCom BA LLB (Hons) LLD LLD (Honoris causa) LLD (Honoris causa)

IT Cohen Professor of International Law and Human Right, Emory University School

of Law; Extraordinary Professor, Department of Private Law, University of Pretoria

\section{OPSOMMING}

Militêre ingrype in Sirië: Die Amerikaanse, Britse en Franse Alternatiewe en die Russiese Opsie

Die gebruik van chemiese wapens deur die Siriese owerheid teen rebellegroepe in die land het dwarsoor die wêreld opslae gemaak. Die Amerikaanse, Britse en Franse owerhede het gedreig met gewapende ingrype teen ongedefinieërde teikens in Sirië, maar het regverdiging vir sodanige ingrype op verskillende gronde gebaseer. Die Britse Eerste Minister David Cameron het gewapende ingrype op grond van humanitêre intervensie probeer regverdig, President Barack Obama van die Verenigde State sou dit op grond van oorwegings van selfverdediging en die verdediging van Amerikaanse bondgenote in die Midde Ooste regverdig, terwyl die Franse Eerste Minister Jean-Marc Ayrault gewag gemaak het van die noodsaak om Sirië te straf vir sy vergrype teen die verbod van internasionele gewoontereg op die gebruik van chemiese wapens.

In hierdie artikel word aangevoer dat hoewel oorlogsmaatreëls in hedendaagse humanitêre reg nie tot die gronde beperk is wat in artikels 42 en 51 van die Handves van die Verenigde Nasies vermeld word nie, die gronde ter regverdiging van gewapende ingrype in Sirië wat deur die staatshoofde van die Verenigde State, Britanje en Frankryk aangevoer is, nie regtens geoorloof is nie. Humanitêre intervensie is tradisioneel gemik op die omverwerping van 'n regering wat sy eie burgers se regte ondermyn, maar al drie lande het dit duidelik gestel dat hulle nie daarop ingestel is om die Siriese regering tot 'n val te bring nie; voorkomende selfverdediging is alleen geregverdig as 'n militêre aanval onmiddellik dreigend is, en nòg die Verenigde State nòg enige van sy bondgenote is met 'n militêre inval bedreig; en strafmaatreëls teen 'n staatsowerheid is 'n uitsluitlike prerogatief van die Veiligheidsraad van die Verenigde Nasies.

Die Russiese Federasie het gevolglik die weg gebaan, naamlik om die aangeleentheid na die Veiligheidsraad te verwys. Dit het daarop uitgeloop dat Sirië verbied is om chemiese wapens te ontwikkel, te verkry of op te berg, en dat Sirië die 1993 Konvensie aangaande die Verbod op die Ontwikkeling, Vervaardiging en Opberging en Gebruik van Chemise Wapens en die Vernietiging van Sodanige Wapens op 14 September 2013 geratifiseer het.

How to cite: Van der Vyver 'Military intervention in Syria: The American, British and French alternatives and the http://dx doi org/10.17159/2225-7160/2015/v48n1a3 


\section{Introduction}

Violence erupted in Syria following a popular demonstration of 15 March 2011, inspired by the Arab Spring, and demanding the resignation of President Bashar al-Assad and an end to the Ba'ath Party's rule. Following the deployment of the Syrian army in April 2011 to suppress the protesting masses, the uprising soon escalated into a full-scale civil war. Efforts by the United Nations, ${ }^{1}$ and the Human Rights Council, ${ }^{2}$ to broker a peace accord failed. By 20 July 2013, the death toll, according to United Nations (UN) estimates, exceeded $100000 .^{3}$ According to some estimates, that number has since then grown to more than 120000 casualties. In a report of the Secretary-General of the UN of 12 August 2012, the number of displaced persons by that time had grown to more than 1 million people. ${ }^{4}$ More recent estimates set the number of displaced persons at close to 2 million, with perhaps double that number having been uprooted within the borders of Syria.

On 21 August 2013, a rocket attack was launched in Syria against rebel forces that have been engaged in attempts to overthrow the government of the country. The attack was aimed at a stronghold of the rebel forces within the eastern suburbs of Damascus and included the use of chemical weapons, which caused indiscriminative deaths, injuries and mutilations of at least 1429 people, including more than 400 children. There are strong indications that the rockets containing chemical weapons were launched by the military forces of the country. ${ }^{5}$ Allegations that the use of chemical weapons was, or possibly was, orchestrated by the rebel forces in an attempt to discredit the Syrian regime were, to say the least,

1 In Security Council (SC) Res 2042 of 2012-04-14, the SC called for the full implementation of a six-point plan proposed by former Secretary-General Kofi Annan, a Joint Special Envoy of the UN, and the League of Arab States to broker peace in Syria; in SC Res. 2043 of 2012-04-21, the SC established the UN Supervision Mission in the Syrian Arab Republic (UNSMIS) to monitor a cessation of armed violence in Syria.

2 On 26 September 2013, the Human Rights Council adopted a proposal by the United States, condemning the ongoing violations of international humanitarian law in Syria, calling for the unfettered access throughout Syria of the UN mandated commission of inquiry and of humanitarian agencies, and expressing the need for accountability of those responsible for serious violations of international humanitarian law and human rights law. The Resolution was adopted by 40 votes to 1 , with 6 abstentions. HRC Res 24/22 on The Continuing Grave Deterioration of the Human Rights and Humanitarian Situation in the Syrian Arab Republic UN Doc A/HRC/24/L.28 (2013-09-26).

3 See statement by the President of the SC UN Doc S/PRST/2013/15 (2013-1002).

4 Report of the Secretary-General, Implementation of General Assembly Resolution 66/253 B on the Situation in Syria par 3 UN Doc A/66/889 (201208-21).

5 See Report of the UN Mission to Investigate Allegations of the Use of Chemical Weapons in the Syrian Arab Republic on the Alleged Use of Chemical Weapons in the Ghouta Area of Damascus on 21 August 2013 UN Doc A/67/997-S/2013/ 553 (2013-08-16). 
highly speculative. Several Western countries, notably the United States, Great Britain and France threatened to respond to the use of chemical weapons by the Syrian military forces by launching an armed attack of some sorts against (unspecified) Syrian targets. Taking matters into their own hands was at least to some extent based on inaction by the Security Council of the UN due to public statements by representatives of Russia and China that any proposal to take action against Syria will be opposed by those countries, and if needs be through the use of their veto powers in the Security Council.

It should be noted at the outset that the bases of an armed response tendered by Great Britain, the United States and France were not the same. Describing the Syrian action as "morally indefensible", and promising to "put an end to human rights atrocities in Syria", British Prime Minister David Cameron seemed to justify an armed response on the basis of humanitarian intervention, while President Barack Obama was quite emphatic in seeking to legitimise a military intervention in Syria on grounds of self-defense. Military intervention, he said, was required (a) to protect American allies in the Middle East, such as Israel, Jordan and Turkey, against the possible use of chemical weapons against them; and (b) taking precautions against the possibility of such weapons falling into the hands of terrorist groups that might use them in attacks aimed at American targets. Statements made by the French Prime Minister Jean-Marc Ayrault suggested that an armed response would serve as a retributive deterrent: The act of Syria, said he, cannot go without response, and an armed response must serve to dissuade Syrian authorities from doing it again.

Be that as it may, the British Parliament on 29 August 2013, in what was described by some as a "stunning defeat" of Prime Minister David Cameron, by 285 votes to 272 , rejected a government-sponsored motion to support in principle military action against Syria. On 10 September 2013, President Obama requested Congress to delay its finding on the matter pending a possible solution to the problem based on a Russian proposal for Security Council intervention, ${ }^{6}$ and in the end the matter never came before Congress. There were strong indications that if the matter had gone before Congress, Congress would most likely have declined to give its blessing to an armed attack in Syria by American forces.

Public discourse in the United States was almost exclusively centred on the question whether Congressional approval of an armed response against Syria was required by the Constitution, which vested in Congress the power "To declare War."7 President Obama sided with those who believed that military intervention in Syria would not amount to a "declaration of war" and that the President, as "Commander in Chief of

6 See President Obama's Address to the Nation on Syria (2013-09-10).

7 Constitution of the United States art I s $8 \mathrm{cl} 10$ 
the Army and Navy of the United States," 8 was competent to order such intervention without Congressional approval. He stated, though, that he would seek Congressional approval so as to ensure that he has the support of the American people for the military action contemplated. The question whether or not an armed intervention would violate international humanitarian law was never part of the political debate in the United States.

\section{International Humanitarian Law Pertaining to the Use, Development, Production and Stockpiling of Chemical Weapons}

Every government has the right to resist efforts of factions within its population attempting to overthrow the regime by unconstitutional means. Such counter-revolutionary strategies may include the use of armed force. However, the means and methods of an armed response are subject to radical limitations, including the use of weaponry that have been outlawed by the rules and regulations of international humanitarian law. The use of chemical weapons in an armed conflict is outlawed by customary international law and constitutes a serious offence. The prohibition on the use of chemical weapons stems from the Geneva Protocol for the Prohibition of the Use in War of Asphyxiating, Poisonous and Other Gasses and Bacteriological Methods of Warfare of $1925 .{ }^{9}$ It has come to be generally accepted that the use of bacteriological and chemical weapons is included in the proscriptive provisions of the 1925 Geneva Protocol. ${ }^{10}$ In 1969, the General Assembly of the UN, in a Resolution on the Question of Chemical and Bacteriological (Biological) Weapons, proclaimed that the 1925 Geneva Protocol embodies generally recognised rules of international law prohibiting the use in international armed conflicts of all biological and chemical methods of warfare, and declared such use to be contrary to the generally recognised rules of international law as embodied in that Protocol. The proscription applies to:

[T]he use in international armed conflicts of:

(a) Any chemical agents of warfare - chemical substances, whether gaseous, liquid or solid - which might be employed because of their direct toxic effects on man, animals or plants;

$8 \quad$ Idem art II s $2 \mathrm{cl} 1$

9 Protocol for the Prohibition of the Use in War of Poisonous and Other Gasses and Bacteriological Methods of Warfare1925, 26 UST 571; TIAS No 8061, 94 LNTS 65. The 1925 Protocol was preceded by the Declaration to Prohibit the Use of Projectiles, the Only Object of Which is the Diffusion of Asphyxiating or Deleterious Gases, 1899 (reprinted in 1 AJIL. (Supp) 157 (1907)).

101925 Protocol supra n 9; and see Meron 'Crimes Under the Jurisdiction of the International Criminal Court' in Herman, von Hebel, Lammers \& Schukking (eds) Reflections on the International Criminal Court: Essays in Honour of Adriaan Bos (1999) 53. 
(b) Any biological agents of warfare - living organisms, whatever their nature, or infective material derived from them - which are intended to cause disease or death in man, animals or plants, and which depend for their effects on their ability to multiply in the person, animal or plant attacked. ${ }^{11}$

It is submitted that the ban on the use of chemical weapons also applies to armed conflicts not of an international character; and the fact that new chemical, bacteriological and biological agents may have been developed subsequent to the date of the Protocol does not detract from its application to such new agents. The Protocol applies "regardless of any technical development". ${ }^{2}$

In more recent times, the international community of states adopted the Convention on the Prohibition of the Development, Production and Stockpiling of Bacteriological and Toxin Weapons and on Their Destruction of $1972,{ }^{13}$ and its counterpart, the Convention on the Prohibition of the Development, Production and Stockpiling and Use of Chemical Weapons and on Their Destruction of $1993 .{ }^{14}$ The 1993 Convention added to the 1925 Protocol on the use of asphyxiating, poisonous and other gasses and bacteriological methods of warfare, the proscription of the development, production and stockpiling of chemical weapons and mandated the destruction of such weapons. At the time of the deployment of chemical weapons in Syria, the 1993 Convention had been ratified by 189 states, including the United States which acceded to the Convention on 25 April 1997. In 2012, the Organisation for the Prohibition of Chemical Weapons verified that the United States, in compliance with its treaty obligations, had destroyed 24912 Mega Tons of chemical weapons which constituted

11 General Assembly (GA) Res 2603 (XXIV) of 1969-12-16 in 24 UN GAOR Supp (No 30) 16 UN Doc A/7630 (1969); and see also Report of the Secretary General on Respect for Human Rights in Armed Conflicts par 192 UN Doc Al 7720 (1969-11-20) urging member states of the UN "in the interests of enhancing the security of peoples around the world" to make a clear affirmation that the prohibitions contained in the 1925 Geneva Protocol applies to the use in war of all chemical, bacteriological and biological agents.

12 GA Res 2603 (XXIV) of 1969-12-16 supra n 11. The Report of the Secretary General refers to the application of the 1925 Protocol to chemical, bacteriological and biological agents "which now exist or which may be developed in future". See also Legality of the Threat or Use of Nuclear Weapons 1996 ICJ 226 par 85 holding that the fact that nuclear weapons did not exist at the time when the rules of international humanitarian law were developed does not mean that their destructive use cannot be brought within the reach of those proscriptions.

13 Convention on the Prohibition of the Development, Production and Stockpiling of Bacteriological and Toxin Weapons and on Their Destruction 19721015 UNTS 26 UST 583, TIAS. No 806211 ILM 309 (1972).

14 Convention on the Prohibition of the Development, Production and Stockpiling and Use of Chemical Weapons and on Their Destruction 19931974 UNTS 45 (1993). 
$89.71 \%$ of its declared stockpile. ${ }^{15}$ Two countries (Israel and Myanmar) have signed the Convention but have not yet ratified it, while five states (Angola, Egypt, North Korea, South Sudan, and Syria) have neither signed nor acceded to the Convention. ${ }^{16}$ Syria announced on 10 September 2013 that it is now willing to sign the treaty, and the Secretary-General of the UN subsequently confirmed that Syria acceded to the 1993 Convention on 14 September 2013. ${ }^{17}$

Even though Syria had not ratified the 1993 Convention at the time of the attack of 21 August 2013, it is highly likely that, given the wide support given to it as evidenced by the large number of ratifications, its provisions will be held to constitute rules of customary international law that would as such be binding on all states, including Syria. For present purposes, though, that is neither here nor there, because Syria is accused of the use of chemical weapons, the prohibition of which dates back to 1925 and which is without any doubt prohibited by customary international law. The question now arises what can be done in response to Syria's unlawful conduct, and in particular whether or not an armed response would be permissible under the prevailing laws and customs of general international law.

\section{The British Response}

Promising to "put an end to human rights atrocities in Syria", British Prime Minister David Cameron seemed to base the legality of an armed intervention in Syria on the principle of humanitarian intervention. Humanitarian intervention, which owes its origin to the writings of Grotius, ${ }^{18}$ occurs when state A takes military action against state B in order to liberate the nationals of state B from ongoing and excessive repressive laws and practices of and in state $B$. The question is, though, whether or not humanitarian intervention is in this day and age still

15 Report of the OPCW on the Implementation of the Convention on the Prohibition of the Development, Production, Stockpiling and Use of Chemical Weapons and on their Destruction par 1.12 Doc C-17/4 (2012-11-27).

16 Idem annex 1 (45\& 46); and see also as to adherence to and compliance with the Chemical Weapons Convention in general by states parties, the report of the US Department of State on Adherence to and Compliance with Arms Control, Nonproliferation and Disarmament Agreements and Commitments 37-51 (2010-07-01).

17 Supra $n$ 5; see also the note by the Secretary-General par 3 UN Doc A/67/ 997-S/2013/553 (2013-09-16).

18 In his seminal work on the law of war and peace, Grotius posed the question "whether there may be a just cause for undertaking war on behalf of the subjects of another ruler, in order to protect them from wrong at his hands" (Grotius De Iure Bellie Ac Pacis Libri Tres (eds) Molhuysen \& van Vollenhoven (1919) 2.25.8(1)). He answered this question in the positive, provided the wrong inflicted by the rules on his own subjects is obvious, explaining: "In conformity with this principle Constantine took up arms against Maxentius and Lucinius, and other Roman emperors either took up arms against the Persians, or threatened to do so, unless these should check their persecutions of the Christians on religious grounds". 
lawful within the confines of contemporary rules of international humanitarian law.

Armed intervention is authorised by the UN Charter in two instances only:

(a) Collective armed intervention under auspices of the Security Council as a means of putting an end to a situation that constitutes a threat to the peace, a breach of the peace or an act of aggression; ${ }^{19}$ and

(b) Individual or collective self-defence in cases where an armed attack occurred against a member state of the UN. ${ }^{20}$

This raises the question whether or not the UN Charter deals comprehensively with the question of legally permissible armed interventions: Are there situations not mentioned in the UN Charter in which a resort to military action would be legal, or at least legitimate, under the rules of international law?

There are compelling reasons to believe that lawful armed interventions under contemporary international humanitarian law are not confined to those sanctioned by the UN Charter. The UN itself has gone beyond its own Charter provisions by affording legitimacy to instances of armed intervention not mentioned in the Charter. In 1950, when the Cold War was still in its infancy, the General Assembly of the UN adopted the Uniting for Peace Resolution, which provides:

... if the Security Council, because of lack of unanimity of the Permanent Members, fails to exercise its primary responsibility for the maintenance of international peace and security in any case where there appears to be a threat to the peace, breach of the peace or act of aggression, the General Assembly shall consider the matter immediately with a view to making appropriate recommendations to Members for collective measures, including in the case of a breach of the peace or an act of aggression the use of armed force when necessary, to maintain or restore international peace and security. ${ }^{21}$

Article 1(4) of Additional Protocol I to the Geneva Conventions of 12 August 1949 afforded special sanction to "armed conflicts in which peoples are fighting against colonial domination and alien occupation

19 See the UN Charter preamble \& art 42.

20 Idem art 51 . In cases of collective self-defence, the state for whose benefit this right is used must declare itself to be the victim of an armed attack. Case concerning Military and Paramilitary Activities in and against Nicaragua (Nicaragua $v$ United States of America): Merits par 1961986 ICJ 13, at 114 (1986-06-27). The victim state must furthermore request the assistance of the other state or states participating in the collective defence of the victim state (Nicaragua case supra at par 199).

21 GA Res 377 (V) (A) of 1950-11-03 5 UN GAOR Supp No 20 at 10 UN Doc A/ 1775 (1950). 
and against racist regimes in the exercise of their right to selfdetermination".22 The legitimacy of wars of liberation against colonial rule, foreign domination and racist regimes has also been acknowledged repeatedly by the General Assembly of the UN. ${ }^{23}$ The General Assembly was quite explicit in saying that the "legitimate struggle" includes the armed struggle of liberation movements. ${ }^{24}$ If the UN, itself, endorsed the legitimacy of armed interventions not mentioned in its Charter, why then not also acknowledge the continued legality of humanitarian interventions?

There are indeed those who bluntly deny the legality of humanitarian intervention without Security Council endorsement. ${ }^{25}$ However, arguments in support of the continued legality, or the moral legitimacy, of humanitarian intervention have been wide-ranging, ${ }^{26}$ and can be reduced to three quite distinct points of departure.

(a) The literalist approach, represented by Julius Stone (1907-1985), maintains that Article 2(4) of the UN Charter does not forbid the threat or use of force simpliciter, but only the threat or use of force for specific unlawful purposes, namely, "against the territorial integrity or political independence of any state, or in any other manner inconsistent with the Purposes of the UN"; and since humanitarian intervention does not seek to change territorial borders of the state under attack or to challenge the political independence of that state, it falls outside the scope of the UN

22 Protocol Additional to the Geneva Conventions of 12 August 1949, and Relating to the Protection of Victims of International Armed Conflicts (Protocol I), 1977, art 1(4) UN Doc A/32/144, 1125 UNTS 3, 16 ILM 1391 (1977).

23 See for example, GA Res 3163 (XXVIII) of 1973-12-14 par 5, 28 UN GAOR Supp (No 30) 5 UN Doc A/9030 (1973) proclaiming the legitimacy of the struggle of the people under colonial and alien domination to exercise their right to self-determination and independence by all necessary means; GA Res 3411 (XXX) of 1975-12-10 par G5, 30 UN GAOR Supp (No 34) at 36 UN Doc A/10034 (1975) proclaiming the legitimacy of the struggle against a racist regime by all means possible; GA Res 35/206A of 1980-12-16 par 1, 35 UN GAOR Supp (No 48) at 29 UN Doc A/35/48 (1980); GA Res 36/172A of 1981-12-17 par 13, 36 UN GAOR Supp (No 51) at 38 UN Doc A/36/51 (1981); and see also SC Res 437 of 1980-06-13, 35 UN SCOR (Res \& Dec) at 18, par 4 UN Doc S/INF/36 (1980) proclaiming the legitimacy of the struggle of the South African people for the elimination of apartheid; and see Schwebel, 'Wars of Liberation as Fought in UN Organs' in Moore (ed) Law and Civil War in the Modern World 218.

24 See for example, GA Res 37/69A of 1982-12-09 par 16, 37 UN GAOR Supp (No 51) 28 UN Doc A/37/51 (1982); GA Res 38/39A of 1983-12-05 par 4, 38 UN GAOR Supp (No 47) 36 UN Doc A/38/47 (1983).

25 See for example, Shukri 'Will Aggressors Ever be Tried Before the ICC?' in Politi \& Nesi The International Criminal Court and the Crime of Aggression (2204) 34-35; Bantekas 'Defences in International Criminal Law' in McGoldrick, Rowe \& Donnelly (eds) The Permanent International Criminal Court: Legal Policy Issues (2004) 278-79 (maintaining that lawful armed intervention is confined to those sanctioned by art $42 \& 51$ of the UN Charter and that pre-emptive self-defence is not legitimate).

26 See Lillich 'A United States Policy of Humanitarian Intervention in Kommers \& Loescher (eds) Human Rights and American Foreign Policy (1979) 288-89; and for a critical analysis of the following classification, see Kemp Individual Criminal Liability for the International Crime of Aggression (2010) 64-68. 
Charter proscription. ${ }^{27}$ Furthermore, one cannot, according to Stone, reconcile a blanket prohibition of the threat or use of force with the provisions of Article 2(3) of the UN Charter, which call upon member states of the UN to settle international disputes by peaceful means and in such a manner that international peace, "and justice", are not endangered. ${ }^{28}$

(b) The flexible and teleological approach, ${ }^{29}$ represented by Michael Reisman, argues that the prohibition of the threat or use of force must be read in conjunction with the overarching human rights concerns of the UN as recorded in several provisions of the UN Charter ${ }^{30}$ and of which humanitarian intervention is a logical extension. ${ }^{31}$

(c) The emergency mechanism argument, represented by Richard Baxter ${ }^{32}$ and Richard Lillich, ${ }^{33}$ bases the justification for humanitarian intervention on a necessity deriving from the imperfections of the Security Council, due to the veto powers of the permanent members and the (then) prevailing Cold War, to execute its primary function of maintaining international peace and security: there is a need for humanitarian intervention exactly because the Security Council has been immobilised by the veto power of the permanent members. This presupposes that humanitarian intervention is to be "deactivated" should the Security Council ever begin to function smoothly.

Although humanitarian intervention remains "a murky area of law and morality", 34 there does seem to be a need for "'a form of collective intervention' beyond the veto-bound Security Council", 35 but then under strict conditions relating, first, to the circumstances that would justify military action in a given situation, and secondly, the manner in which it is to be executed. Humanitarian intervention will only be warranted in exceptional cases of extreme, and at the time ongoing, violations of human rights; ${ }^{36}$ and as to execution of an armed intervention, collective rather than unilateral action must be the norm. Humanitarian

27 Stone Aggression and World Order (1958) 95; and see contra Schachter 'The Right of States to Use Armed Force' 1984 Mich L Rev 16201633.

28 Stone supra $\mathrm{n} 27$ at $95 \& 98-101$

29 See Brownlie 'Humanitarian Intervention' in Moore supra n 23 at 218.

30 UN Charter preamble $\&$ arts $1,55 \& 56$.

31 Reisman 'Humanitarian Intervention to Protect the Ibos' in Lillich (ed) Humanitarian Intervention and the United Nations (1973) 177-178; and see also Roberts supra $n 19$ at 8 .

32 Baxter (discussant in conference proceedings) in Lillich supra n 31 at 54 (“... it is almost as if we were thrown back on customary international law by a breakdown of the Charter system").

33 Lillich supra n 26 at 289; and see also Lillich 'Forcible Self-Help by States to Protect Human Rights' 1967 Iowa L Rev 325335 \& 345-351; Lillich 'Humanitarian Intervention: A Reply to Ian Brownlie and a Plea for Constructive Alternatives' in Moore supra n 23 at 230.

34 Smith 'Moral Hazard and Humanitarian Law: The International Criminal Court and the Limits of Legalism' 2002 Int. L \& Politics 175189.

35 Henkin 'Kosovo and the Law of Humanitarian Intervention' 1999 Am J Int L 824828.

36 Kritsiotis ‘Arguments of Mass Confusion' 2004 Eur J Int L 233273 (noting that states have reserved the right of humanitarian intervention for extreme situations of acute or aggravated humanitarian need). 
intervention has thus been defined as "the use of military force consensual or otherwise - by regional and international bodies to prevent or stop massive and systematic human rights violations". 37 Human Rights Watch emphasised that "advocating non-consensual military intervention only when it is the last feasible option to avoid genocide or comparable mass slaughter", adding that "given the risk to life inherent in any military action, only the most severe threats to life should warrant consideration of an international armed response". 38

There are a number of prominent international lawyers, on the other hand, who maintain that humanitarian intervention is decidedly illegal but might in special circumstances derive a certain morally-defined justification, basing their reluctance to subscribe to the legality of humanitarian intervention on its potential abuse. ${ }^{39}$ Richard Falk, for example, argues that the legitimacy, if not the legality, of retaliation and the same, it is submitted, would apply to humanitarian intervention derives from the "acceptability" of the use of force in the special circumstances that prompted its use: ${ }^{40}$

The assumption underlying such an approach is that the primary role of international law is to help governments plan how to act, rather than to permit some third-party judge to determine whether contested action is legal or not. In fact the function of the third-party judge can be performed properly only by attempting to assess in what respects and to what extent the governmental actor "violated" community norms of a presumptive nature. ${ }^{41}$

Jonathan Charney, commenting on the Kosovo bombings, likewise maintained that "keeping such intervention illegal and requiring states to break the law in extreme circumstances may be the best and most likely way to limit its abuse, despite not being a perfect solution". ${ }^{2}$ The moral appeal of the use of force "would tend to mitigate or even overcome any perceived 'illegality", of such action. ${ }^{43}$

Assuming, though, that humanitarian intervention would be the way to go in extreme cases of human rights abuses, the British proposal for taking such action in Syria is problematic in quite a different respect. The

37 Monshipouri \& Welch 'The Search for International Human Rights and Justice: Coming to Terms with New Global Realities' Hum Rts Q 2001370 378; and see also Smith supra n 34 at 178.

38 Human Rights Watch World Report Events of 19992000 at xix.

39 Kritsiotis 'Reappraising Policy Objections to Humanitarian Intervention' 1998 Mich J Int L 1005 1020-21; see also Smith supra n 34 at 183.

40 Falk 'The Beirut Raid and the International Law of Retaliation' 1969 Am J Int $L 415$ 425) (arguing that certain behaviour might be acceptable though not legal).

41 Idem 442

42 Charney 'Anticipatory Humanitarian Intervention in Kosovo' 1999 Am J Int L 834 838; and see also Friedman 'Comment' in Moore supra n 23 at 578579 (maintaining that concepts such as humanitarian intervention have at best attained the level of accepted international morality rather than law).

43 Falk supra n 40 at 439 ("also proclaiming that [a] rule of conduct isolated from context is often too abstract to guide choice of action"). 
purpose of humanitarian intervention is invariably the toppling of a repressive regime and the reinstatement of the rule of law under a newlyelected government. However, Britain, France and the United States made it clear that the purpose of an armed intervention in Syria would not be geared toward the overthrow of the current regime. The problem that confronted the states concerned was that creating a situation in which the rebel forces might gain political control would most likely be bad news for the West because those rebel forces have close links with Al-Qaeda and seem to uphold quite radical political views.

\section{The American Alternative}

President Barack Obama based the legitimacy of an armed attack against (undefined) targets in Syria on considerations of self-defence and the defence of allied countries in the region such as Israel, Jordan and Macedonia. The problem with this approach is that none of the countries mentioned have been attacked by Syria or are under threat of an armed attack.

Article 51 of the UN Charter authorises individual or collective selfdefence in cases where an armed attack occurred against a member state of the UN. ${ }^{44}$ The question whether or not this provision precludes anticipatory self-defence action is, in itself, problematic, since that article by its own wording only authorises individual or collective self-defence "if an armed attack occurs". 45 Does this mean that one should wait until the enemy has slapped you in the face before you can punch him on the nose?

It stands to reason that a state need not wait for the other side to strike the first blow if it is abundantly clear and absolutely certain that an armed attack is imminent. ${ }^{46}$ As noted by Sir Humphrey Waldock:

Where there is convincing evidence not merely of threats and potential danger but of an attack being actually mounted, then an armed attack may be said to have begun to occur, though it has not passed the frontier. ${ }^{47}$

Some analysts relied on reference in Article 51 to "the inherent right of individual or collective self-defence” [emphasis added] could arguably

44 UN Charter art 51

45 See Alexandrov Self-Defence against the Use of Force in International Law (1996) 165; O'Connell The Myth of Preemptive Self-Defence (2002) 5 available from http://www.asil.org/taskforce/oconnell.pdf (interpreting art 51 to mean that an attack must be underway or must have already occurred in order to trigger the right to unilateral self-defence).

46 See Reisman 'International Legal Responses to Terrorism' 1999 Houston J Int L 3 17; and see also Arend \& Beck International Law and the Use of Force: Beyond the UN Charter Paradigm (1993) 186 (stating that "[w]ith the demise of Article 2(4), it is reasonable to assume that this preexisting right [to anticipatory self-defence] would be rehabilitated").

47 Waldock 'The Regulation of the Use of Force by Individual States in International Law' in Recueil des Cours (1952) 498. 
include pre-emptive action. ${ }^{48}$ The inherent right to self-defence includes more than merely taking defensive action after an attack has occurred; reference to individual or collective self-defence "if an attack occurs" was intended "to list [merely] one situation in which a state could clearly exercise that right". 49

In its National Security Strategy of 2002, the United States endorsed the right to pre-emptive self-defence action:

The United States has long maintained the option of preemptive actions to counter a sufficient threat to our national security. The greater the threat, the greater the risk of inaction - and the more compelling the case for taking anticipatory action to defend ourselves, even if uncertainty remains as to the time and place of the enemy's attack. To forestall or prevent such hostile acts by our adversaries, the United States will, if necessary, act preemptively. ${ }^{50}$

The General Assembly of the UN has also endorsed a right to preemptive self-defence action, proclaiming “... a threatened state, according to established international law, can take military action as long as the threatened attack is imminent, no other means would deflect it and the action is proportionate". 51 It should be noted, though, that whereas the United States used the concepts of "pre-emptive" and "anticipatory" action interchangeably, ${ }^{52}$ the General Assembly made a distinction between "pre-emptive" and "anticipatory" self-defence action, defining the former concept as action "against an imminent or proximate threat" and the latter as action "against a non-imminent and non-proximate one". ${ }^{53}$ Even though it could be argued "that the potential harm from some threats (eg, terrorist armed with a nuclear weapon) is so great that one simply cannot risk waiting until they become imminent, and that less harm may be done (eg, avoiding a nuclear exchange or radioactive fallout from a reactor destruction) by acting earlier", 54 international law requires "that if there are good arguments for preventive military action, with good evidence to support them, they should be put to the Security Council, which can authorise such action if it chooses to". 55 And what if the Security Council for whatever reason should not authorise anticipatory defensive action? Then, said the General Assembly, "there will be, by definition, time to pursue other

48 Arend \& Beck supra n 46 at 72-73; and see O'Connell supra n 45 at 12; O'Connell 'Review Essay: Re-leashing the Dogs of War' 2003 Am J Int L 446 453.

49 Arend \& Beck supra n 46 at 73

50 The National Security Strategy of the United States 200215 (2002-09-17) available from http://www.au.af.mil/au/awc/awcgate/nss/nss_sep2002.pdf.

51 Report of the High-Level Panel on Threats, Challenges and Change UN Doc A/ 59/565 at par 188 (2 Dec 2004).

$52 \mathrm{Ibid}$; and note that this writer has also in the past used the two terms interchangeably; see van der Vyver 'Ius Contra Bellum and American Foreign Policy' 2003 Sou Afr Y B Int'l L 1 4-5.

53 Supra n 51; supra n 11 at par 189.

54 Ibid.

55 Idem 190 
strategies, including persuasion, negotiation, deterrence and containment - and to visit again the military option". 56

It is commonly accepted that pre-emptive self-defence must be confined to the circumstances specified by Secretary of State Webster in a diplomatic communique to his British counterpart in the case of The Caroline; that is to say, pre-emptive action must be confined to cases in which the "necessity of that self-defence is instant, overwhelming, and leaving no choice of means, and no moment of deliberation". 57 Jordan Paust has pointed out that The Caroline incident was not actually a matter of pre-emptive self-defence since it occurred in the process of continued attacks on the government of Canada by insurgents. ${ }^{58}$ That may be the case, but it is equally true that the citation from The Caroline has come to be regarded as the decisive norm governing pre-emptive military action. ${ }^{59}$ It was, for example, quoted by the Nuremberg Military Tribunal in the context of preventive armed intervention. ${ }^{60}$ Pre-emptive selfdefence must therefore, remain confined to "situations in which the imminence of an attack is so clear and the danger so great that defensive action is essential for self-preservation". 61 It must also comply with the test of proportionality. ${ }^{62}$

It should be evident to everyone that Syria had no intention whatsoever to launch an armed attack against the United States or against any of its allies in the region. That being the case, an armed attack by American forces against targets in Syria cannot even with any stretch of the imagination be justified on self-defence grounds - anticipatory, pre-emptive or otherwise!

\section{The French Connection}

French Prime Minister Jean-Marc Ayrault's proposal that Syria should be rapped over the knuckles for its unlawful and highly unbecoming act was the least persuasive of all the reasons advanced by Western powers for an armed attack against selected Syrian targets. In his Address to the Nation on Syria of 10 September 2013, President Obama conceded that "we [the United States] should not be the world's policeman". That is a

56 Ibid.

57 'The Caroline' in Moore (ed) Digest of International Law (1906) 412; Lori, Henkin, Pugh, Schachter \& Smit International Law: Cases and Materials (2001) 922-923.

58 Paust 'Use of Armed Force against Terrorists in Afghanistan, Iraq, and Beyond' 2002 Cornell Int'l LJ 533535.

59 See Waldock supra $\mathrm{n} 47$ at 498; Reisman, supra n 46 at 47 \& 48-49.

60 United States \& Others $v$ Göring \& Others, Trials of the Major War Criminals Before the International Military Tribunal, Nuremberg 14 November 1945 1 October 1946, Judgment 171 at 207. Nuremberg: Int'l Mil. Tribunal (1946-49).

61 Schachter 'The Right of States to Use Armed Force' 1984 Mich L Rev 1620 1634 (1984).

62 Arend \& Beck supra $\mathrm{n} 46$ at 249 
fair assessment of the laws and customs of general international law. However, governments are fully entitled to take punitive action against foreign states for good reasons. Such action could include the severance of diplomatic relations, the interruption of trade relations, and the cessation of means of communication. Such unfriendly acts are part and parcel of state sovereignty. Engaging in an armed response to the unlawful conduct of the other state is not included in the retributory package authorised by contemporary international law as a matter of retorsion. It is trite law, today, that the Security Council of the UN is the only body in the world that can take punitive action against states whose conduct constitutes a threat to the peace, a breach of the peace or an act of aggression.

This raised the question in my mind whether or not French courts could perhaps prosecute the persons responsible for the deployment of chemical weapons in Syria under the rubric of universal jurisdiction. French courts can only exercise universal jurisdiction relating to customary law crimes in exceptional cases. ${ }^{63}$ It is thus not within their general power to prosecute crimes against humanity or the crime of genocide committed by foreigners beyond the country's territorial borders. The French Code of Criminal Procedure does make provision for the exercise of universal jurisdiction in respect of specific crimes against humanity stipulated in crime creating conventions incorporated into French municipal law where the conventions authorise the exercise of jurisdiction by national courts, ${ }^{64}$ such as the crime of torture, ${ }^{65}$ acts of terrorism, ${ }^{66}$ terrorist bombing, ${ }^{67}$ and the financing of terrorism; ${ }^{68}$ and the offence of enforced disappearance. ${ }^{69}$ The events in Syria do not fall within any of these specific categories.

63 See in general International Federation for Human Rights - Legal Action Group, France: Universal Jurisdiction, Status of the Implementation of the Principle of Universal Jurisdiction, no 431/2 (2005).

64 Code de procedure pénale art 689. See also International Federation for Human Rights - Legal Action Group, France Universal Jurisdiction: Status of the Implementation of the Principle of Universal Jurisdiction (2005) n 431/ 2 .

65 Idem art 689-2 based on the International Convention against Torture and Other Cruel, Inhuman and Degrading Treatment or Punishment of $10 \mathrm{Dec}$ 1984.

66 Idem art 689-3 based on the European Convention on the Suppression of Terrorism of 27 Jan 1977; and the Agreement concerning the Application of the European Convention on the Suppression of Terrorism among the Member States of the European Communities of 4 Dec 1979.

67 Idem art 689-9 based on the International Convention for the Suppression of Terrorist Bombing, signed on 12 Jan 1998.

68 Idem art 689-10 based on the International Convention for the Suppression of the Financing of Terrorism, signed on 10 Jan 2000.

69 Idem art 689-13 based on the International Convention for the Protection of All Persons from Enforced Disappearance, adopted by the General Assembly of the UN on 20 Dec 2006, signed on 2007-02-06 and entered into force on 2010-12-23. 
Other offences incorporated into French law and which have been subjected to universal jurisdiction include failure to protect nuclear facilities and material in peaceful domestic use or storage or being transported and to take rapid measures to locate and recover stolen or smuggled nuclear material, or to anticipate any radiological consequences of sabotage and to combat related offences; ${ }^{.70}$ unlawful acts against the safety of marine navigation, ${ }^{71}$ and against the safety of fixed platforms located on the continental shelf; ${ }^{72}$ the unlawful seizure of aircraft, ${ }^{73}$ and against the safety of civil navigation; ${ }^{74}$ unlawful acts of violence at airports serving international civil aviation; ${ }^{75}$ acts in violation of financial interests of the European Community, ${ }^{76}$ and corruption involving officials of member states of the European Union. ${ }^{77}$ The French law of criminal procedure also established "quasi universal" jurisdiction for the prosecution of certain road offences within the European community. ${ }^{78}$ Here, too, the deployment of chemical weapons in a foreign country does not fit the bill.

As far as crimes within the jurisdiction of the International Criminal Court (ICC) are concerned, the French Code of Criminal Procedure authorises the exercise of universal jurisdiction by French courts in cases where the ICC has declined to exercise jurisdiction and no other state has asserted jurisdiction or requested the extradition of the person suspected of having committed the crime. $^{79}$ For the exercise of universal jurisdiction in such cases, the Code of Criminal Procedure further requires that the suspect is currently residing in France, that the criminal act is punishable under the national law of the territorial state (the state where the crime was committed), and that the territorial state is a state party to the ICC Statute. ${ }^{80}$ This again excludes Syrian nationals from prosecution in French courts. It does raise the question, though, whether those responsible for the deployment of chemical weapons in Syria can be brought to trial in the ICC.

70 Idem art 689-4 based on the Convention for the Physical Protection of Nuclear Material, signed on 1990-03-03.

71 Idem art 689-5 based on the Convention for the Suppression of Unlawful Acts against the Safety of Maritime Navigation of 10 Mar 1988.

72 Ibid based on the Protocol for the Suppression of Unlawful Acts against the Safety of Fixed Platforms Located on the Continental Shelf of 10 Mar 1988.

73 Idem art 689-6 based on the Convention for the Suppression of Unlawful Seizure of Aircraft, signed on 1970-12-16.

74 Ibid based on the Convention for the Suppression of Unlawful Acts against the Safety of Civil Aviation, signed on 1997-09-23.

75 Idem art 689-7 based on the Protocol for the Suppression of Unlawful Acts of Violence at Airports Serving Civil Aviation of 24 Feb 1988.

76 Idem art 689-8 based on the Protocol to the Convention on the Protection of the European Communities' Financial Interests of 27 Sep 1996.

77 Ibid based on the Convention on the Fight against Corruption Involving Officials of the European Communities or Officials of Member States of the European Union of 25 May 1997.

78 Idem art 689-12 based on Regulation (EC) No 561/2006 of the European Parliament and of the Council of 15 Mar 1996.

79 Idem art 689-11.

80 Ibid. 


\section{Prosecuting the Offenders in the ICC}

Several well-intended analysts have proposed that the persons responsible for the rocket attacks in Syria be brought to trial to the ICC. ${ }^{81}$ It must be noted that the ICC can only prosecute the individuals responsible for a crime within the subject-matter jurisdiction of the ICC and that since Syria has not ratified the ICC Statute, the matter can only be brought to trial if the situation in Syria is referred to the ICC by the Security Council of the UN pursuant to its Chapter VII powers. This means, among other things, that a Security Council resolution referring the situation in Syria to the ICC can be vetoed by any one of the permanent members of the Council.

The Security Council, in a Resolution of 27 September 2013, expressed "its strong conviction that those individuals responsible for the use of chemical weapons in the Syrian Arab Republic should be held accountable". 82 This raised the question whether the Security Council envisaged reference of the situation in Syria for investigation by the ICC. It should be noted in this regard that:

- Since Syria has not ratified the ICC Statute and has not otherwise consented to the exercise of jurisdiction by the ICC, the matter can only be investigated by the Office of the Prosecutor following a Security Council referral;

- Since the Security Council Resolution of 27 September 2013 represented a compromise proposal orchestrated by the Russian Federation and the United States, one could expect that neither of those two states, nor any of the other permanent members of the Security Council, will veto a referral of the situation to the ICC;

- The responsible person or persons cannot be prosecuted in the ICC for the war crime of "[e]mploying asphyxiating, poisonous or other gasses, and all analogous liquids, materials or devices," since the crime in question only comes within the subject-matter jurisdiction of the ICC if the employment of such weapons occurred in an international armed conflict; 83

- The Review Conference that was held in Kampala, Uganda on 31 May to 11 June 2010, adopted, by general agreement, a proposal submitted by Belgium for the inclusion in the subject-matter jurisdiction of the ICC the employment of asphyxiating, poisonous or other gasses, and all

81 Those calling for a referral of the situation in Syria to the ICC include Nuremberg Prosecutor Benjamin Ferencz. National Public Radio, Nuremberg Prosecutor Makes the Case for Trying Assad (2013-09-08), available from http://www.nrp.org/2013/09/08/220037023/nurembergprosecutor-makes-the-case-for-trying-assad.htp.

82 SC Res 2118 (2013) par 15 UN Doc S/RES/2118 (2013-09-27).

83 Statute of the International Criminal Court (the ICC Statute) art 8(2)(b)(xviii) $\&$ (ii) UN Doc A/Conf.183/9 (1998-07-17). 
analogous liquids, materials or devices in an armed conflict not of an international character; 84

- Entry into force of the Kampala amendments to the ICC Statute requires 30 ratifications and it has not yet reached that goal; 85

- Even though persons responsible for the employment of chemical weapons in Syria, therefore, cannot be prosecuted in the ICC for the war crime based on the same because the conflict in Syria is not an international armed conflict, they can be brought to trial in the ICC for the use of chemical weapons as a variety of crimes against humanity. ${ }^{86}$

However, in the end, reference of the situation in Syria to the ICC was not to be. A resolution drafted by France for referral of the situation in Syria to the ICC was vetoed by China and Russia on 22 May 2014.

\section{Russia Having the Final Say}

Ratification by Syria of the Convention on the Prohibition of the Development, Production and Stockpiling and Use of Chemical Weapons and on Their Destruction was clearly the outcome of an agreement reached between Russia and the United States on 14 September 2013, on a framework for the elimination of chemical weapons in the Syrian Arab Republic. Russia was from the outset strongly opposed to any punitive action against Syria, let alone an armed attack against Syrian targets. It also became quite evident that President Obama would most likely not get Congressional approval for such an attack. President Obama maintained that he could order such an attack without Congressional approval, but would nevertheless ask for such approval so as to ensure that he has the support of the American people. Embarking on discussion with Russian authorities was most likely sparked by the prospect of suffering the same kind of defeat which Prime Minister Cameron suffered in the British Parliament. Be that as it may, it was eventually decided that Syria will immediately set technologies in motion, under UN supervision, for the destruction of its chemical weapons. The Security Council on 27 September 2013, having noted that "the use of chemical weapons anywhere constitutes a threat to international peace and security", 87 while condemning "in the strongest terms any use of chemical weapons in the Syrian Arab Republic", 88 decided accordingly:

(a) [T]hat the Syrian Arab Republic shall not use, develop, produce, otherwise acquire, stockpile or retain chemical weapons, or transfer,

84 Idem art 8(2)(e)(xiv), inserted pursuant to ICC-ASP/RC/Res 5 annex I (201006-11); and see also ICC-ASP/RC/Res 5 annex II (amending the Elements of Crimes accordingly).

85 Countries that have thus far ratified the Kampala amendments to the ICC Statute include Botswana, Estonia, Germany, Liechtenstein, Luxembourg, Samoa, Trinidad and Tobago and Uruguay.

86 See for example, Meron 'Crimes Under the Jurisdiction of the International Criminal Court' in von Hebel, Lammers \& Schukking supra $\mathrm{n} 10$ at 55.

87 SC Res 2118 (2013) supra $\mathrm{n} 82$ at par 1.

88 Idem par 2 
directly or indirectly, chemical weapons to other states or non-state actors, ${ }^{89}$ and

(b) [T]hat the Syrian Arab Republic shall comply with all aspects of the decision of the OPCW Executive Council of 27 September $2013 .{ }^{90}$

The plan of action of the Organisation for the Prohibition of Chemical Weapons (OPCW) for the destruction of Syrian chemical weapons, which is attached to the Security Council Resolution, ${ }^{91}$ was based on a Framework for Elimination of Syrian Chemical Weapons agreed upon by the United States and the Russian Federation on 14 September $2013 .{ }^{92}$ Considering the responses of the Heads of State of France, Great Britain and the United States to the use of chemical weapons in Syria, it is fair to conclude that, in this matter, the Russian Federation has set the international community of states on the right course.

It must be emphasised in conclusion that an armed attack by the Western countries would have constituted a profound violation of international humanitarian law. The UN Charter demands that all member states "shall settle their international disputes by peaceful means in such a manner that international peace and security, and justice, are not endangered". 93 To France, one should say, that the maintenance of international peace and security is a primary function of the Security Council of the UN, ${ }^{94}$ and that punitive action against states whose conduct constitutes a threat to the peace, a breach of the peace, or an act of aggression can only be imposed by the Security Council. ${ }^{95}$ President Obama should be reminded that the United States and its allies in the Middle East were not under threat of an impending and immediate attack and that pre-emptive self-defence is only permissible in circumstances in which the "necessity of that self-defence is instant, overwhelming, and leaving no choice of means, and no moment of deliberation". 96 Prime Minister Cameron of Great Britain was on the right track by seeking to justify an armed attack against Syria on the basis of humanitarian intervention, because the situation in Syria most certainly complied with the demands for militant humanitarian action. However, his Western allies made it quite clear that they will not seek to topple the Ba'ath Party rule and to replace President Bashar al-Assad as Head of State; and replacement of as repressive government is exactly what humanitarian intervention is designed to achieve. It was generally feared in the Western countries that toppling the current government of Syria and placing the country under the rule of the rebel forces might be bad

89 Idem par 4

90 Idem par 6

91 Idem annex I.

92 OPCW Executive Council Joint National Paper by the Russian Federation and the United States of America: Framework for Elimination of Syrian Chemical Weapons UN Doc EC-M-33/NAT.1 (2013-09-17).

93 UN Charter supra $\mathrm{n} 4$ at art $2(3)$.

94 Idem art 24(1).

95 Idem arts 39-42.

96 'The Caroline' supra n 57. 
news for the West because there are clear indications that the rebel groups include quite radical Islamic forces with links to Al Qaeda.

In conclusion, it might be mentioned that it was at times suggested that the United States and its allies should perhaps provide weapons and afford logistical support to the rebel forces in Syria so as to enable them to topple the repressive government. The idea did not find favour with persons in authority, exactly because of the radical trends among the rebel forces. In addition, it should be borne in mind that the Nicaragua Case is authority for the proposition that if the government of state A is under threat of militant rebel forces, it could lawfully request state B to support it in its military efforts to suppress the uprising, but it would be unlawful under the current rules of international law for state B to afford military support to the rebels that are trying to overthrow the government of a member state of the UN. ${ }^{97}$

97 See Case Concerning Military and Paramilitary Activities in and against Nicaragua (Nicaragua $v$ United States of America) supra $\mathrm{n} 20$ at par 196. 